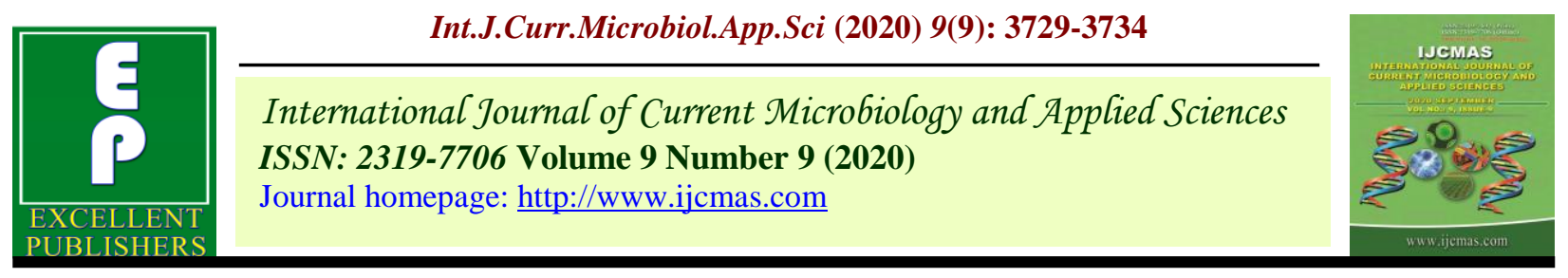

Original Research Article

https://doi.org/10.20546/ijcmas.2020.909.460

\title{
Cultural Variability of Different Isolates of Cotton Alternaria spp. on Different Media
}

\author{
K. Pranaya*, Bharati N. Bhat, G. Uma Devi and S. Triveni
}

Department of Plant Pathology, College of Agriculture, Professor Jayashankar Telangana State Agricultural University, Rajendranagar, Hyderabad-030, Telangana, India

*Corresponding author

\section{A B S T R A C T}

Cotton (Gossypium hirsutum L.) is the one of the most important commercial crops of

\section{Keywords}

Cotton,

Alternaria spp.,

Different Media

\section{Article Info}

Accepted:

28 August 2020

Available Online:

10 September 2020 the world, which belongs to the family Malvaceae. India is the largest cotton growing country in the world with an area of around $12.35 \mathrm{M}$ ha accompanied by United States and China with production of $36.1 \mathrm{M}$ bales and productivity of $524 \mathrm{~kg}$ lint/ha. Cotton crop is known to suffer from number of fungal, bacterial and viral diseases. In India foliar diseases have been estimated to cause yield losses up to 38 per cent. Cotton is under persistent threat of foliar diseases like grey mildew, Alternaria leaf spot, Myrothecium leaf spot, bacterial leaf blight, rust etc. Cultural variability among the twelve isolates were studied by growing isolates on different media i.e., Cotton leaf extract agar, Potato dextrose agar, Oat meal agar. Among the media tested, cotton leaf extract agar supported good growth of the fungus with excellent radial growth and high sporulation followed by potato dextrose agar and while least sporulation was observed on Oat meal agar.

\section{Introduction}

Cotton is the most essential natural fiber crop in the world for textile produce, accounting for about $50 \%$ of all fibers used in the textile industry. It is grown all over the world in about 80 countries. Cotton is unique among agricultural crops, because it is the main natural fiber crop, and also provides edible oil. It is one of the agro-industrial crops which are produced in both developing and developed countries (Bedane and Arkebe, 2019).
India is the largest cotton growing country in the world with an area of around $12.35 \mathrm{M}$ ha followed by United States and China with production of $36.1 \mathrm{M}$ bales and productivity of $524 \mathrm{~kg}$ lint/ha (Cotton Association of India, 2018-2019). India's share in global cotton exports is around 25 percent In India, Maharastra (26.63\%), Gujarat (17.96\%), Andhra Pradesh (13.75\%) and also Madhya Pradesh are the leading cotton producing states. Cotton in India provides direct livelihood to 6 million farmers and about 40 50 million people are employed in cotton trade and its processing (Chitte et al., 2019). 
The word "cotton" is derived from Arabic word (qutnor qutun). This was the usual word for cotton in medieval Arabic. Cotton (Gossypium spp.) belongs to the botanical family Malvaceae. Cotton is referred to as "King of Fibres" and also known as "White Gold" (Prasad et al., 2018).

There are four cultivated species of cotton viz., Gossypium arboreum, G. herbaceum, $G$. hirsutum and $G$. barbadense. The first two species are diploid $(2 n=26)$ and are native to old world. The last two species are tetraploid $(2 \mathrm{n}=52) . \quad G$. hirsutumis the predominant species which alone contributes about 90 per cent to the global production. Perhaps, India is the only country in the world where all the four cultivated species are grown on commercial scale (Chitte et al., 2019).

The various species of cotton grown as agricultural crops are native to subtropical parts of the world. Cotton can be found as perennial tree like plants in tropical climate but is normally cultivated as a shrubby annual in temperate climates.

Cotton is a heat loving crop. During germination it requires $32-34{ }^{\circ} \mathrm{C}$ and $25-27{ }^{\circ} \mathrm{C}$ during the vegetative stage. Average temperature of $21-22{ }^{\circ} \mathrm{C}$ is required for the crop (Sangameshwari et al., 2019). It is grown between latitudes $30^{\circ} \mathrm{N}$ and $30^{\circ} \mathrm{S}$.

\section{Materials and Methods}

\section{Cotton leaf extract agar (MA)}

$\begin{array}{lll}\text { Agaragar } & : & 20 \mathrm{~g} \\ \text { Dextrose } & : & 20 \mathrm{~g} \\ \text { Maizeleaves }: & 200 \mathrm{~g} \\ \text { Distilled water: } & 1000 \mathrm{ml}\end{array}$

Two hundred grams of cotton leaves were boiled in $500 \mathrm{ml}$ of distilled water in a 1000 $\mathrm{ml}$ beaker for $30 \mathrm{~min}$. The extract was filtered through a double layered muslin cloth. To another $500 \mathrm{ml}$ of distilled water in another $1000 \mathrm{ml}$ beaker, $20 \mathrm{~g}$ of agar agar was added and melted till it gets dissolved. Both the solutions were mixed in another $1000 \mathrm{ml}$ beaker into which $20 \mathrm{~g}$ of dextrose was added. The final volume of the medium was made up to $1000 \mathrm{ml}$ by addition of sterile distilled water. The $\mathrm{pH}$ of the media was adjusted 6.8 by $1 \mathrm{~N} \mathrm{NaOH}$ or $1 \mathrm{~N} \mathrm{HC} 1$. Two hundred and fifty $\mathrm{ml}$ of the media was then transferred to $500 \mathrm{ml}$ conical flask and were sterilized in an autoclave at $121^{\circ} \mathrm{C}$ and 15 Psi for 20 minutes. The sterilized media was stored in a refrigerator for further use.

\section{Potato dextrose agar (PDA) medium}

PDA medium was prepared using the following components for culturing the fungi in the laboratory.

Potato (peeled, washed and sliced): $200 \mathrm{~g}$ Dextrose : $20 \mathrm{~g}$

Agaragar : $20 \mathrm{~g}$

Distilledwater : $1000 \mathrm{ml}$

Two hundred gram of potatoes were taken, peeled and cut into small pieces and boiled for 20 to $30 \mathrm{~min}$. After boiling extract was filtered through muslin cloth. Dextrose and agar were added in equal amount and boiled until properly dissolved. Sterilization was done $121{ }^{\circ} \mathrm{C}$ for $15 \mathrm{~min}$. Twenty $\mathrm{ml}$ of media (PDA) was poured into sterilized Petriplates and kept for solidification.

\section{Oat Meal Agar (OMA)}

Oatflakes : $30 \mathrm{~g}$

Agar-agar : $20 \mathrm{~g}$

Distilled water: $1000 \mathrm{ml}$ (volume to make up)

Oat flakes were boiled in $500 \mathrm{ml}$ distilled water for $30 \mathrm{~min}$ and filtered through muslin cloth. Agar agar was melted in $500 \mathrm{ml}$ 
distilled water separately. Both the solutions were mixed thoroughly and the volume was made up to $1000 \mathrm{ml}$ and was sterilized was done $121^{\circ} \mathrm{C}$ and 15 psi for $15 \mathrm{~min}$.

Twenty ml of media (PDA) was poured into sterilized petriplates and kept for solidification. After solidification, each treatment was replicated thrice. $5 \mathrm{~mm}$ discs of the Alternaria spp. were cut using a cork borer and a single disc was placed on the slat. Each set of the experiment was replicated twice and the plates were incubated at $27 \pm 1$ ${ }^{\circ} \mathrm{C}$ for 12 days. After 15 days, the observation of diameter of radial growth, type of colony margin, colour of margin, mycelial growth, sectoring and sporulation were recorded. Sporulation was graded as per (Sangeetha K. D., 2014)

\section{Results and Discussion}

\section{Cultural characteristics of different isolates of Alternaria spp. on Cotton leaf extract agar}

The data pertaining to cultural characteristics of different isolates Alternaria spp. was recorded twelve days after incubation on medium at $25 \pm 1^{\circ} \mathrm{C}$.

\section{Colony colour}

The colony colour of fungus was recorded based on dominant spectral colour from Munsell's soil colour chart (1951), twelve days after incubation on medium. The colony colour varied from grey to black colour.

Based on the colony colour, all the twelve isolates were grouped into four categories i.e., white, black, ashy and greyish. Isolate N1A, $\mathrm{A} 2 \mathrm{~A}$ and isolate $\mathrm{A} 4 \mathrm{~A}$ showed white. Isolates N2A, N3A, N4A and M3A showed black while isolates, A3A, M1A and M4A showed greyish.
Isolates M2A and A1A showed ashy colour.

\section{Colony margin colour}

The margin colour of culture medium of all the twelve isolates were grouped into three categories i.e., white, black, greyish colour.

There was significant difference among the isolates with regard to colony margin in the culture medium.

The isolates N1A, A2A and M3A showed white margin. Isolates N2A, A3A, N3A, N4A and M4A showed black margin while Isolates M1A, A1A, A4A and M2A exhibited greyish margin.

\section{Type of margin}

All twelve isolates showed varied type of margin from raised to flat. Isolates M1A, $\mathrm{M} 3 \mathrm{~A}$ and M4A had flat type of margin whereas, isolates like N1A, N4A, A3A, N3A, N2A, A2A, M2A, A1A and A4A had raised type of margin.

\section{Radial growth}

All the isolates showed full plate growth $90.00 \mathrm{~mm}$ except one isolate A2A with least radial growth of $85.33 \mathrm{~mm}$.

\section{Sporulation}

All the twelve isolates of Alternaria spp. were classified into three groups based on the sporulation. Excellent sporulation was observed in isolate N2A. The isolates, N1A, A1A, N4A, A4A and M2A recorded very good sporulation. Good sporulation was observed in isolate N3A while, poor sporulation was seen in isolates M1A, M3A, M4A and A2A. 
Table.1 The sporulation grade for Alternaria spp

\begin{tabular}{|l|l|l|l|}
\hline $\begin{array}{l}\text { Sl. } \\
\text { No. }\end{array}$ & Score & Grade & $\begin{array}{l}\text { Description No. of spores/microscopic field } \\
(\mathbf{1 0})\end{array}$ \\
\hline $\mathbf{1}$ & ++++ & Excellent sporulation & $\mathbf{3 0}$ spores/microscopic field \\
\hline $\mathbf{2}$ & +++ & Good sporulation & $\mathbf{2 1 - 3 0}$ spores/microscopic field \\
\hline $\mathbf{3}$ & ++ & Moderate sporulation & $\mathbf{1 1 - 2 0}$ spores/microscopic field \\
\hline $\mathbf{4}$ & + & Poor sporulation & $\mathbf{1 - 1 0}$ spores/microscopic field \\
\hline $\mathbf{5}$ & - & No sporulation & $<\mathbf{1}$ spores/microscopic field \\
\hline
\end{tabular}

Table. 2 Cultural characteristics of different isolates of Alternaria spp. on cotton leaf extract agar

\begin{tabular}{|l|l|l|l|l|l|l|}
\hline S.NO & Isolate & $\begin{array}{l}\text { Colony } \\
\text { color }\end{array}$ & $\begin{array}{l}\text { Colony } \\
\text { colourmargin }\end{array}$ & $\begin{array}{l}\text { Type of } \\
\text { margin }\end{array}$ & $\begin{array}{l}\text { Radial } \\
\text { growth }\end{array}$ & Sporulation \\
\hline $\mathbf{1 .}$ & N1A & White & White & Raised & 90.00 & +++ \\
\hline $\mathbf{2 .}$ & N2A & Black & Black & Raised & 90.00 & ++++ \\
\hline $\mathbf{3 .}$ & N3A & Black & Black & Raised & 90.00 & ++ \\
\hline $\mathbf{4 .}$ & N4A & Black & Black & Raised & 90.00 & +++ \\
\hline $\mathbf{5 .}$ & M1A & Greyish & Greyish & Flat & 90.00 & +++ \\
\hline $\mathbf{6 .}$ & M2A & Ashy & Greyish & Raised & 90.00 & +++ \\
\hline $\mathbf{7 .}$ & M3A & Black & White & Flat & 90.00 & + \\
\hline $\mathbf{8 .}$ & M4A & Greyish & Black & Flat & 90.00 & + \\
\hline $\mathbf{9 .}$ & A1A & Ashy & Greyish & Raised & 90.00 & +++ \\
\hline $\mathbf{1 0 .}$ & A2A & White & White & Raised & 85.33 & + \\
\hline $\mathbf{1 1 .}$ & A3A & Greyish & Black & Raised & 90.00 & +++ \\
\hline $\mathbf{1 2 .}$ & A4A & White & Greyish & Raised & 90.00 & ++++ \\
\hline & & & C.D. & $\mathbf{0 . 9 8 9}$ & \\
\hline
\end{tabular}

Table.3 Cultural characteristics of different isolates of Alternaria spp. on potato dextrose agar

\begin{tabular}{|l|l|l|l|l|l|l|}
\hline S.NO & Isolate & $\begin{array}{l}\text { Colony } \\
\text { colour }\end{array}$ & $\begin{array}{l}\text { Colony colour } \\
\text { margin }\end{array}$ & $\begin{array}{l}\text { Type of } \\
\text { margin }\end{array}$ & $\begin{array}{l}\text { Radial } \\
\text { growth }\end{array}$ & Sporulation \\
\hline $\mathbf{1 .}$ & N1A & White & White & Flat & 90.00 & ++++ \\
\hline $\mathbf{2 .}$ & N2A & Black & Black & Flat & 90.00 & ++++ \\
\hline $\mathbf{3 .}$ & N3A & Black & Black & Flat & 82.00 & ++ \\
\hline $\mathbf{4 .}$ & N4A & Black & Black & Raised & 90.00 & +++ \\
\hline $\mathbf{5 .}$ & M1A & Greyish & Greyish & Raised & 90.00 & ++++ \\
\hline $\mathbf{6 .}$ & M2A & Black & Greyish & Raised & 78.33 & ++ \\
\hline $\mathbf{7 .}$ & M3A & Ashy & Greyish & Flat & 90.00 & ++ \\
\hline $\mathbf{8 .}$ & M4A & Greyish & Black & Flat & 90.00 & +++ \\
\hline $\mathbf{9 .}$ & A1A & White & Greyish & Flat & 90.00 & +++ \\
\hline $\mathbf{1 0}$ & A2A & Black & Black & Raised & 90.00 & ++ \\
\hline $\mathbf{1 1}$ & A3A & Ashy & White & Flat & 90.00 & ++++ \\
\hline $\mathbf{1 2 .}$ & A4A & White & White & Raised & 42.00 & ++ \\
\hline & & & & C.D. & $\mathbf{1 . 7 8 7}$ & \\
\hline
\end{tabular}


Table.4 Cultural characteristics of different isolates of Alternaria spp. on oat meal agar

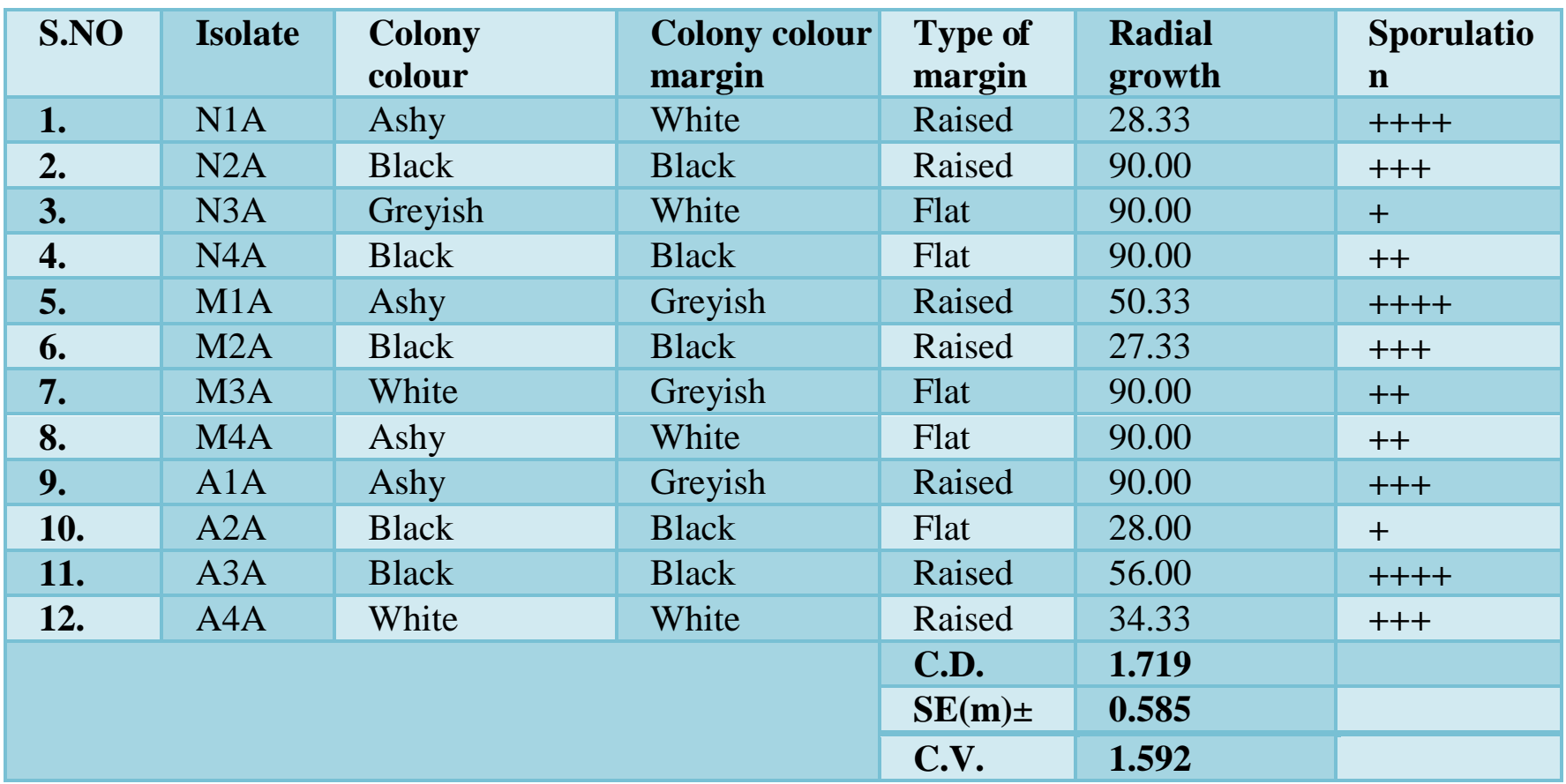

Cultural characteristics of different isolates of Alternaria spp. on Potato dextrose agar

\section{Colonycolour}

Based on the colony colour, all the twelve isolates were grouped into four categories (as described earlier in 4.2.1.1). The isolates $\mathrm{N} 1 \mathrm{~A}, \mathrm{~A} 1 \mathrm{~A}$ and $\mathrm{A} 4 \mathrm{~A}$ showed white. The isolates N4A, N3A, N2A and M2A showed black colour. Whereas, the isolate M1Aand M4A has showed greyish black colour, and isolate $\mathrm{A} 2 \mathrm{~A}, \mathrm{M} 3 \mathrm{~A}$ and $\mathrm{A} 3 \mathrm{~A}$ exhibited ash colour.

\section{Colony margin colour}

The margin colour of culture medium of all the twelve isolates were grouped into three categories i.e., white, black and greyish colour.

Isolate $\mathrm{N} 1 \mathrm{~A}, \mathrm{~A} 3 \mathrm{~A}, \mathrm{~A} 2 \mathrm{~A}$ and $\mathrm{A} 4 \mathrm{~A}$ showed white margin. Isolates like M1A, M2A, M3A, A1A showed greyish colour margin, whereas, isolates like N4A, N2A, M4A and N3A exhibited black margin.

\section{Type of margin}

All twelve isolates showed varied type of margin from raised to flat. Isolates N4A, M1A, A2A, M2A and A4A had raised type of margin. Whereas isolates like N1A, A3A, N3A, N2A, M4A, A1A and M3A showed flat type of margin.

\section{Radial growth}

The highest radial growth was observed in N1A, N2A, N4A, M1A, M3A, M4A, A1A, $\mathrm{A} 2 \mathrm{~A}$ and $\mathrm{A} 3 \mathrm{~A}$ isolates with $90.00 \mathrm{~mm}$ followed by $\mathrm{N} 3 \mathrm{~A}$ isolate $(82.00 \mathrm{~mm})$ and M2A $(78.33 \mathrm{~mm})$, least radial growth was observed in A4A isolate $(42.00 \mathrm{~mm})$.

\section{Sporulation}

Excellent sporulation was observed in isolate $\mathrm{N} 2 \mathrm{~A}$ and isolate $\mathrm{A} 3 \mathrm{~A}$. While the isolates, N1A, N4A, A1A and M1A, M4A recorded very good sporulation. Good sporulation was observed in isolate $\mathrm{A} 4 \mathrm{~A}$ and isolate M3A while, poor sporulation was seen in isolates $\mathrm{N} 3 \mathrm{~A}, \mathrm{~A} 2 \mathrm{~A}$, andM2A. 


\section{Cultural characteristics of different isolates of Alternaria spp. on oat meal- agar Colony colour}

Based on the colony colour, all the twelve isolates were grouped into four categories as described earlier in 4.2.1.1. The isolates A1A, $\mathrm{A} 4 \mathrm{~A}$ and $\mathrm{M} 3 \mathrm{~A}$ showed white colour. Isolates like N4A, A3A, N2A, A2A and M2A showed black whereas isolates like N1A and M4A showed ashy. Isolates like M1A and N3A showed greyish.

\section{Colony margin colour}

Isolates $\mathrm{N} 1 \mathrm{~A}, \mathrm{M} 4 \mathrm{~A}$ and $\mathrm{A} 4 \mathrm{~A}$ showed white margin. Isolates M1A, A1A and M3A showed greyish colour margin whereas isolates like N4A, A3A, N3A, N2A, A2A, M2A exhibited black margin.

\section{Type of margin}

All twelve isolates showed varied type of margin from raised to flat. Isolates N1A, A3A, M1A, M2A, N2A, A4A and A1A had raised type of margin. Whereas isolates like N4A, N3A, M4A, A2A and M3A showed flat type of margin.

\section{Radial growth}

The highest radial growth was observed in isolates N2A, N3A, N4A, M3A, M4A, A1A $(90.00 \mathrm{~mm})$ followed by A3A $(56.00 \mathrm{~mm})$, M1A (50.33 mm), A4A (34.33 mm), N1A $(28.33 \mathrm{~mm})$. Lowest radial growth was observed in isolate M2A $(27.33 \mathrm{~mm})$.

\section{Sporulation}

Excellent sporulation was observed in isolate M1A, A3A and isolate N4A. While the isolates, N1A, N2A, A4A and M4A recorded very good sporulation. Good sporulation was observed in isolate A1A, M2A and isolate M3A while, poor sporulation was seen in isolates $\mathrm{N} 3 \mathrm{~A}, \mathrm{~A} 2 \mathrm{~A}$.

\section{References}

Prasad, B., Bhattiprolu, S.L., Prasanna Kumari, V and Anil kumar, P. 2018. In vitro evaluation of fungicides against Alternaria macrospora causing leaf spot in cotton. International Journal of Current Microbiology and Applied Sciences. 7(1): 2551-2557.

BedaneGudeta and ArkebeEgziabher, G. 2019. Cotton production potential areas, production trends, research status, gaps and future directions of cotton improvement in Ethiopia. Greener Journal of Agricultural Sciences. 9:163-170.

Cotton Association of India. 2018-2019. Cotton Statistics and News. 41(4): 3-8.

Chitte Karishma, Taley, S.M., Atal, G.R., Paslawar, A.N and Katkar, R.N. 2019. Impact of tillage practices on crop growth and production in cotton under rainfed condition. Journal of Pharmacognosy and Phytochemistry. 8(4): 858-861.

Sangameshwari, P., Kumarimanimuthu Veeral, D and Ganapathy, M. 2019. Analysis of growing degree days for cotton. International Journal of Recent Scientific Research. 10: 31548-31550.

Sangeetha, K.D. 2014. Studies on variability and management of Alternaria spp. causing leaf blight of cotton. Thesis, University of Agricultural Sciences, Dharwad. pp. 97.

\section{How to cite this article:}

Pranaya, K., Bharati N. Bhat, G. Uma Devi and Triveni, S. 2020. Cultural Variability of Different Isolates of Cotton Alternaria spp. on Different Media. Int.J.Curr.Microbiol.App.Sci. 9(09): 3729-3734. doi: https://doi.org/10.20546/ijcmas.2020.909.460 